

\title{
Conserved motifs in the invertebrate iridescent virus 6 (IIV6) genome regulate virus transcription
}

\author{
Journal of Invertebrate Pathology \\ Yesilyurt, Aydin; Demirbag, Zihni; Oers, Monique M.; Nalcacioglu, Remziye \\ https://doi.org/10.1016/j.jip.2020.107496
}

This article is made publicly available in the institutional repository of Wageningen University and Research, under the terms of article $25 \mathrm{fa}$ of the Dutch Copyright Act, also known as the Amendment Taverne. This has been done with explicit consent by the author.

Article 25 fa states that the author of a short scientific work funded either wholly or partially by Dutch public funds is entitled to make that work publicly available for no consideration following a reasonable period of time after the work was first published, provided that clear reference is made to the source of the first publication of the work.

This publication is distributed under The Association of Universities in the Netherlands (VSNU) 'Article $25 \mathrm{fa}$ implementation' project. In this project research outputs of researchers employed by Dutch Universities that comply with the legal requirements of Article $25 \mathrm{fa}$ of the Dutch Copyright Act are distributed online and free of cost or other barriers in institutional repositories. Research outputs are distributed six months after their first online publication in the original published version and with proper attribution to the source of the original publication.

You are permitted to download and use the publication for personal purposes. All rights remain with the author(s) and / or copyright owner(s) of this work. Any use of the publication or parts of it other than authorised under article $25 \mathrm{fa}$ of the Dutch Copyright act is prohibited. Wageningen University \& Research and the author(s) of this publication shall not be held responsible or liable for any damages resulting from your (re)use of this publication.

For questions regarding the public availability of this article please contact openscience.library@wur.nl 


\title{
Conserved motifs in the invertebrate iridescent virus 6 (IIV6) genome regulate virus transcription
}

\author{
Aydin Yesilyurt $^{\mathrm{a}, \mathrm{b}}$, Zihni Demirbag ${ }^{\mathrm{a}}$, Monique M. van Oers ${ }^{\mathrm{b}}$, Remziye Nalcacioglu ${ }^{\mathrm{a},}$ \\ ${ }^{a}$ Department of Biology, Faculty of Science, Karadeniz Technical University, 61080 Trabzon, Turkey \\ ${ }^{\mathrm{b}}$ Laboratory of Virology, Wageningen University and Research, 6708 PB Wageningen, the Netherlands
}

\section{A R T I C L E I N F O}

\section{Keywords:}

Transcriptional analysis

Promoter sequence

Repressor

Iridovirus

\begin{abstract}
A B S T R A C T
Invertebrate iridescent virus 6 (IIV6) is the type species of the Iridovirus genus in the Betairidovirinae subfamily of the Iridoviridae family. Transcription of the 215 predicted IIV6 genes is temporally regulated, dividing the genes into three kinetic classes: immediate-early (IE), delayed-early (DE), and late (L). So far, the transcriptional class has been determined for a selection of virion protein genes and only for three genes the potential promoter regions have been analyzed in detail. In this study, we investigated the transcriptional class of all IIV6 genes that had not been classified until now. RT-PCR analysis of total RNA isolated from virus-infected insect cells in the presence or absence of protein and DNA synthesis inhibitors, placed 113, 23 and 22 of the newly analyzed viral ORFs into the IE, DE and L gene classes, respectively. Afterwards, in silico analysis was performed to the upstream regions (200 bp) of all viral ORFs using the MEME Suite Software. The AA(A/T)(T/A)TG(A/G)A and (T/A/C)(T/ G/C)T(T/A)ATGG motifs were identified in the upstream region of IE and DE genes, respectively. These motifs were validated by luciferase reporter assays as crucial sequences for promoter activity. For the $\mathrm{L}$ genes two conserved motifs were identified for all analyzed genes: $(T / G)(C / T)(A / C) A(T / G / C)(T / C) T(T / C)$ and $(C / G / T)(G /$ $A / C)(T / A)(T / G)(G / T)(T / C)$. However, the presence of these two motifs did not influence promoter activity. Conversely, the presence of these two sequences upstream of the reporter decreased its expression. Single nucleotide mutations in the highly conserved nucleotides at the end of the second motif (TTGT) showed that this motif acted as a repressor sequence for late genes in the IIV6 genome. Next, upstream sequences of IIV6 L genes from which we removed this second motif in silico, were re-analyzed for the presence of potential conserved promoter sequences. Two additional motifs were identified in this way for L genes: (T/A)(A/T)(A/T/G)(A/T)(T/ $\mathrm{C})(\mathrm{A} / \mathrm{G})(\mathrm{A} / \mathrm{C})(\mathrm{A} / \mathrm{C})$ and $(\mathrm{C} / \mathrm{G})(\mathrm{T} / \mathrm{C})(\mathrm{T} / \mathrm{A} / \mathrm{C}) \mathrm{C}(\mathrm{A} / \mathrm{T})(\mathrm{A} / \mathrm{T}) \mathrm{T}(\mathrm{T} / \mathrm{G})(\mathrm{T} / \mathrm{G})(\mathrm{T} / \mathrm{G} / \mathrm{A})$. Independent mutations in either motif caused a severe decrease in luciferase expression. Information on temporal classes and upstream regulatory sequences will contribute to our understanding of the transcriptional mechanisms in IIV6.
\end{abstract}

\section{Introduction}

Invertebrate iridescent viruses (IIVs, family Iridoviridae, subfamily Betairidovirinae, genus Iridovirus) form icosahedral particles of 120-180 nm in diameter (Chinchar et al., 2017). Virions comprise a $\mathrm{DNA}$ /protein core surrounded by an internal lipid membrane, a protein capsid and in the case of those particles that bud out of cells, an outer viral envelope. IIVs have been reported to infect over 100 species of arthropods (Williams et al., 2017). Invertebrate iridescent virus 6 (IIV-6), also known as Chilo iridescent virus (CIV), is the type species of the Iridovirus genus. The IIV6 genome consists of 212,482 bp of linear dsDNA (Jakob and Darai, 2002) with 215 non-overlapping and putative protein-encoding ORFs selected from the 468 computationally predicted
ORFs (Eaton et al., 2007). Proteomic analysis has shown that IIV6 particles contain 54 structural, viral-encoded proteins (Ince et al., 2010). The replication of the IIV6 genome is presumed to be essentially similar to that of Frog virus 3 (FV3), the type species of the genus Ranavirus, in the subfamily Alphairidovirinae (Granoff, 1984; Williams and Ward, 2010). Viral genome replication starts in the nucleus and is followed by genome concatamerization and subsequent cleavage, particle assembly and maturation in the cytoplasm (Goorha, 1982). Since purified IIV6 DNA is not infectious, one or more virion-associated proteins are needed for the initiation of IIV gene transcription (Cerutti et al., 1989).

A previous study on IIV6 mRNAs detectable by northern blot analysis revealed three temporal transcript classes in IIV6 infections: immediateearly (IE), delayed-early (DE) and late (L) (D'Costa et al., 2001). Thirty

\footnotetext{
* Corresponding author.
} 
eight of the detected transcripts were synthesized in the presence of protein synthesis inhibitors and were classified in the IE class; thirty four transcripts were produced in the presence of DNA synthesis inhibitors and were classified in the DE class, while 65 five transcripts were detected only in the absence of inhibitors and were classified in the $\mathrm{L}$ class. However, as the transcripts were classified prior to genome sequencing, the relationship between the ORFs and their temporal classification was not previously established. In a later study, the 54 IIV6 structural virion protein genes were analyzed for their temporal expression, showing that the majority of these were expressed as IE genes (Ince et al., 2013).

It is known that IIV6 transcripts possess generally short $5^{\prime}$ untranslated regions and lack poly A tails (Nalcacioglu et al., 2003). On the other hand, information regarding the promoter elements of IIV6 genes is rather limited. So far, potential promoter regions of only three IIV6 genes, exonuclease (012L, IE), DNApol (037L, DE) and major capsid protein gene ( $\mathrm{mcp}$ ) (274L, L), have been characterized in detail (Nalcacioglu et al., 2003; 2007; Dizman et al., 2012). These promoters have been identified by means of a luciferase reporter assay in conjunction with deletion mutagenesis of the sequences in the 5 'upstream region of the respective ORFs. In the current study, we investigated the transcriptional class of all as of yet unclassified IIV6 ORFs (170 transcripts) to complete the temporal classification and to be able to search for essential, conserved promoter motifs in IIV6 genes. Therefore, the upstream regions of all genes in a particular class (classified in this paper and in previous studies) were compared and analyzed for conserved sequence motifs. The identified conserved sequences were examined for promoter activity in insect cells using the luciferase reporter assay.

\section{Material and methods}

\subsection{Cell line, virus and virus infections}

Spodoptera frugiperda 9 (Sf9) cells were maintained in Sf-900 II SFM (Gibco) supplemented with $5 \%$ fetal bovine serum (FBS, Sigma) at $28{ }^{\circ} \mathrm{C}$ as monolayer. Invertebrate iridescent virus 6 (IIV6) was propagated in these cells and the virus titer was determined in End Point Dilution Assays (EPDAs) (Cook et al., 1976). Virus infections were carried out with $2 \times 10^{6} \mathrm{Sf} 9$ cells in 6 -well plates, infected at a multiplicity of infection (MOI) of 2 . For the temporal classification of the genes, cultures were pre-treated $1 \mathrm{~h}$ before infection with cytosine-1- $\beta$-D-arabinofuranoside (Ara-C, $100 \mu \mathrm{g} / \mathrm{ml}$ ) and cycloheximide (CHX, $150 \mu \mathrm{g} / \mathrm{ml}$ ) to inhibit DNA and protein synthesis, respectively. The inhibitors remained present during the infection.

\subsection{Reverse transcription PCR (RT-PCR)}

To determine the temporal expression classes of IIV6 genes, RNA isolated as described below was subjected to RT-PCR. Forward and reverse gene specific primers were designed to amplify suitable regions from all viral genes (Table S1). Total RNA was isolated from infected and mock-infected Sf 9 cells at $12 \mathrm{~h}$ post infection (p.i.) using Trizol Reagent (Sigma, T9424) following the manufacturer's instructions. Isolated RNA samples were treated with DNase I (Sigma, AMPD1-1KT) to remove any residual DNA and then extracted with phenol-chloroform. For cDNA synthesis, $1 \mu \mathrm{g}$ of total RNA was mixed with $1 \mu \mathrm{l}(10 \mu \mathrm{M})$ gene specific reverse primer and the total volume was adjusted to $12 \mu \mathrm{l}$ with water. After incubation at $65{ }^{\circ} \mathrm{C}$ for $5 \mathrm{~min}$, the samples were cooled on ice. Subsequently, $4 \mu \mathrm{l}$ reaction buffer (5X), $1 \mu \mathrm{l}$ RiboLock RNase inhibitor $(20 \mu / \mu \mathrm{l}), 2 \mu \mathrm{l} \mathrm{dNTP} \operatorname{mix}(10 \mathrm{mM})$ and $1 \mu \mathrm{l}$ reverse transcriptase (Thermo Scientific, RevertAid M-MuLV RT, $200 \mathrm{u} / \mu \mathrm{l}$ ) were gently mixed in and reactions were incubated at $42{ }^{\circ} \mathrm{C}$ for $60 \mathrm{~min}$. The cDNA synthesis was terminated by heating at $70{ }^{\circ} \mathrm{C}$ for $5 \mathrm{~min}$. and the resulting cDNA mixture was then used as template for gene specific PCR amplifications with forward and reverse primers. PCR products were analyzed in a 1\% agarose gel stained with ethidium bromide. PCR performed with cDNA, obtained from infected cells in absence of inhibitors, was used as positive control (PC).

\subsection{Conserved sequence analyses}

MEME (multiple expectation maximization for motif elicitation) (Bailey et al., 2009) software was used to search for conserved sequences in IIV6 noncoding sequences in the $200 \mathrm{nt}$ regions upstream of the translation initiation codons. To that aim, the upstream sequences were categorized based on experimental data (IE, DE or L) to be able to compare upstream sequences within each expression class. Parameters were set to zero or one occurrence per sequence and we searched only the provided (coding) strand.

\subsection{Plasmid construction}

Upstream sequences of selected genes from each temporal group were investigated to determine whether conserved motifs, found with the MEME software, are indeed important for promoter activity. One gene was selected from each of the three groups. 193R, 126R and 259R were selected as models for IE, DE and L class genes, respectively. Upstream regions of these genes were tested for promoter activity in combination with a luciferase reporter system. Subsequently, upstream sequences of two additional L genes, 061R and 084L were also investigated with this system. Two different regions were amplified from each upstream region; one is the long one containing the conserved motif (wt) and the other is the short one missing the motif (del for E and DE or deLL1 $+L 2$ in case of $L$ genes). These DNA fragments were amplified from the viral genome using two different forward primers and a common reverse primer, for each gene (Table 1). The resulting PCR products, containing $K p n I$ and HindIII sites at $5^{\prime}$ and $3^{\prime}$ ends, respectively, were ligated into the pJET1.2/blunt cloning vector (Thermo). Subsequently these fragments were cloned into upstream of the luciferase reporter ORF of the pSPLuc + vector (Promega), again using the restriction sites at the ends of the fragments.

\subsection{Transfection and luciferase assay}

Sf9 cells $\left(2.5 \times 10^{6}\right.$ cells/well) in 6-well plates were infected with IIV6 for $2 \mathrm{~h}$ and then transfected using Cellfectin (Invitrogen) with plasmid DNA $(1 \mu \mathrm{g})$ harboring the upstream sequences. The various putative promoter constructs were tested in parallel. At $24 \mathrm{~h}$ after transfection, cells were collected by centrifugation at $1000 \mathrm{~g}$ for $5 \mathrm{~min}$. Firefly luciferase activities were measured in cell extracts using the single luciferase reporter assay system (Promega) following the manufacturer's instructions. Transfections were conducted in triplicate, and average values are reported.

\subsection{Site directed mutagenesis}

Highly conserved sequences, found in the upstream regions of the $\mathrm{L}$ gene 061R were mutated to understand the role of these sequences in determining promoter activity. Mutations were performed by PCR using primers specific for the upstream region of 061R, but carrying a number of mismatched nucleotides (Table 1) (Nalcacioglu et al., 2003). Amplified sequences were first cloned into the pJET1.2/blunt cloning vector and then transferred to the pSPLuc + vector, as described above.

\section{Results}

\subsection{Transcriptional classification of all IIV6 transcripts}

To be able to categorize the whole set of genes in the IIV6 genome according to their transcriptional classes, we examined the expression of 170 IIV6 genes at the transcriptional level by RT-PCR. The other 45 genes in the IIV6 genome have previously been classified 
Table 1

Primers for the promotor analyses.

\begin{tabular}{|c|c|c|}
\hline Primers & $\operatorname{Tm}\left({ }^{\circ} \mathbf{C}\right)$ & Primer sequences $\left(5^{\prime}-3^{\prime}\right)$ \\
\hline 193R-prom-Fw & 46.4 & GGTACCGAGGATTTAAAAAAGTTTTAATTTAAA \\
\hline 193R-del-Fw & 46.4 & $\overline{\underline{G G T A C C} T T C A A A A T T A A T A A T A C A T G A T A C A A T ~}$ \\
\hline 193R-prom-Rv & 48.1 & 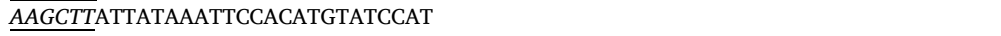 \\
\hline 126R-prom-Fw & 50.1 & $\overline{\text { GGTACCGGTTTTATAAAACAATTAGCACAATTT }}$ \\
\hline 126R-del-Fw & 45.2 & $\overline{\text { GGTACC GATAACCATTAAAAATTATAAATAATTG }}$ \\
\hline 126R- prom-Rv & 47.4 & 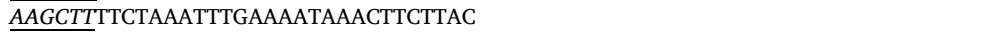 \\
\hline 259R-prom-Fw & 50.4 & $\overline{\text { GGTACC GGTATTTTCGTAATTCATTTCTTGAT }}$ \\
\hline 259R-del-Fw & 50.8 & $\overline{\text { GGTACC GGATTGATGCTTTTAAATGAAAAATATG }}$ \\
\hline 259R- prom-Rv & 51.7 & 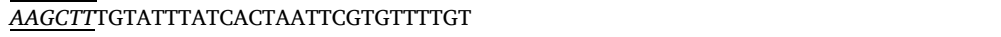 \\
\hline 084L- prom-Fw & 50.5 & $\overline{\text { GGTACCTAAAGTTTCAATTTTGGAAGTTCG }}$ \\
\hline 084L-del-Fw & 50.5 & $\overline{\text { GGTACCAACTAATGGAAGAAGACTTTCAG }}$ \\
\hline 084L- prom-Rv & 49.5 & $\overline{\text { AAGCTTAGGAGACATTCTTTTATTTACAATTAA }}$ \\
\hline 061R-prom-Fw & 46.9 & 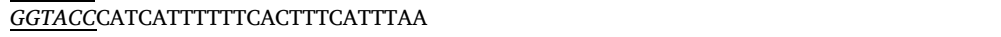 \\
\hline 061R-del-Fw & 45.9 & 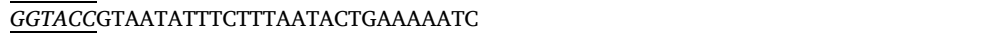 \\
\hline 061R- prom-Rv & 46.9 & 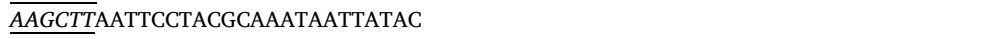 \\
\hline 061R-mutL1-Fw & 63.5 &  \\
\hline 061R-mutL2-Fw & 62.4 & 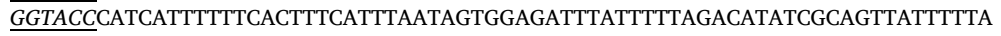 \\
\hline 061R-mutL3-Fw & 60.1 & GGTACCACTGTTCCGACGACGTTGATATTAAACACTACTAT \\
\hline 061R-mutL4-Fw & 58.7 & $\overline{\text { GGTACCACTGAAAAATCAAAGTTGATATGCCTCTGTTGTAT }}$ \\
\hline
\end{tabular}

KpnI (GGTACC) and HindIII (AAGCTT) are shown in italicized and underlined.

transcriptionally (Nalcacioglu et al., 2007; Ince et al., 2008; 2013; Dizman et al., 2012) and were not examined again, except for 012L (IE), 037L (DE) and 274L (L) that were used as positive controls in the current study. In order to classify the IIV6 genes, Sf9 cells were infected with IIV6 in the presence or absence of cycloheximide, which inhibits de novo polypeptide synthesis, and Ara-C, an inhibitor of DNA replication. Total cellular RNA was extracted from cells at $12 \mathrm{~h}$ p.i. and analyzed for the presence of IIV6 transcripts using gene specific primers. In infected cells, a total of 113 newly analyzed transcripts was detected in the presence of protein or DNA synthesis inhibitors, which means that viral protein synthesis and DNA replication are not necessary for these transcripts and therefore they are classified in the IE class (Fig. 1). The number of the additional transcripts detected in the presence of only the DNA synthesis inhibitor was 23 (Fig. 2A). Since these transcripts do not require viral DNA replication but require viral protein synthesis to be transcribed, they were classified in the DE class, and indeed the DE-positive control (037L) was also detected here. The other transcripts that were not detected in the presence of either inhibitors, were classified in the $\mathrm{L}$ class. The number of the late transcripts among the 170 newly tested ORFs was 22 (Fig. 2B). However, no RT-PCR products were obtained from the putative transcripts of 12 ORFs (069L, 121R, 146R, 148R, 201R, 212L, 236L, 238R, 315L, 414L, 426R, 463L). With the previously classified IIV6 genes, the total number of IE, DE and L genes became 138, 35 and 30, respectively.

Among the 138 IE genes identified in total, 61 have a known or a putative function according to gene ontology information obtained from the UniProt database. Eight of the $35 \mathrm{DE}$ transcripts, have an identified or a predicted function. The remaining 27 transcripts of the DE class do not contain a known domain to predict their function (Table 2). The third set of transcripts, classified as L, includes 7 genes with a known or putative function and 23 genes of unknown function (Table 2).

\section{Conserved motifs in the upstream region of IIV6 genes}

After grouping the genes in the three temporal classes, sequences upstream of the translational start codon of each gene were investigated for the presence of conserved and potentially important motifs for promoter activity. For each classified group of genes, motifs were generated by the MEME Suite database (Fig. 3). The AA(A/T)(T/A)TG(A/G)A and $(\mathrm{T} / \mathrm{A} / \mathrm{C})(\mathrm{T} / \mathrm{G} / \mathrm{C}) \mathrm{T}(\mathrm{T} / \mathrm{A})$ ATGG sequences were identified with high probability as conserved motifs in the upstream regions of IE and DE genes, respectively (Fig. 3A-B). The program run for the upstream sequences of the 138 IE genes identified the conserved motif in all of these genes. However, for the 35 scanned DE genes, the motif obtained was only observed in 20 genes. For late genes the program detected two conserved motifs, (T/G)(C/T)(A/C)A(T/G/C)(T/C)T(T/C) (motif L1) and $(\mathrm{C} / \mathrm{G} / \mathrm{T})(\mathrm{G} / \mathrm{A} / \mathrm{C})(\mathrm{T} / \mathrm{A})(\mathrm{T} / \mathrm{G})(\mathrm{G} / \mathrm{T})(\mathrm{T} / \mathrm{C})$ (motif L2), with a similar and high probability in the upstream regions of all scanned late genes (Fig. 3C-D). The locations of all these upstream motifs respective to the translation start site varies for each gene.

\subsection{Investigating the motifs for promoter activity}

To analyze the influence of the conserved motifs on promoter activity, deletion mutagenesis was performed on the upstream regions of 193R, 126R and 259R ORFs, belonging to the IE, DE and L classes, respectively. Two fragments, one containing the motif and the other not, were prepared for each ORF. Reporter plasmids harboring the wild type (wt) or mutant sequence upstream of a firefly luciferase reporter ORF, were transfected into $S f 9$ cells. Cell lysates, obtained $24 \mathrm{~h}$ after transfection, were tested for luciferase activity.

The reporter plasmids that carried the wild type (wt) upstream regions for IE or DE genes (pSP193Rprom, pSP126Rprom), produced high luciferase activity, but the plasmids without the motif (pSP193Rdel, pSP126Rdel) produced a low activity (Fig. 4A-B). However, for L genes, the result was opposite. The plasmids containing both the L1 and L2 motifs produced a low luciferase activity (pSP259Rprom, pSP084Lprom, pSP061Rprom), but the plasmids without these two motifs (pSP259RdelL1 + L2, pSP084LdelL1 + L2, pSP061RdelL1 + L2) produced a high activity. This result was validated with two additional late genes $(061 \mathrm{~L}, 084 \mathrm{~L})$ by preparing similar deletion mutations and testing the luciferase activity as mentioned above (Fig. 4C).

\subsection{Site-directed mutations in conserved late gene motifs}

To analyze these L motifs in more detail, we modified the L1 and L2 motifs in the upstream region of 061R individually by PCR using primers with mismatches. Reporter plasmids were prepared carrying both L1 and L2 motifs, but one unmutated sequence and the other mutated, to determine the impact of such changes on promoter activity. Mutation of motif L1 (mutation 1) did not affect the promoter activity, however mutation at motif L2 (mutation 2) increased promoter activity. This result demonstrates that motif $\mathrm{L} 2$ acts as a repressor on $\mathrm{L}$ gene promoter activity by a factor of over $90 \%$ (Fig. 5). The fact that expression levels were not fully restored to high levels by deleting L2, suggest that L1 is insufficient for a fully-functional promoter sequence.

The fact that the detected L motifs do not act as promoters led us to search for other conserved sequences that might have promoter activity. 


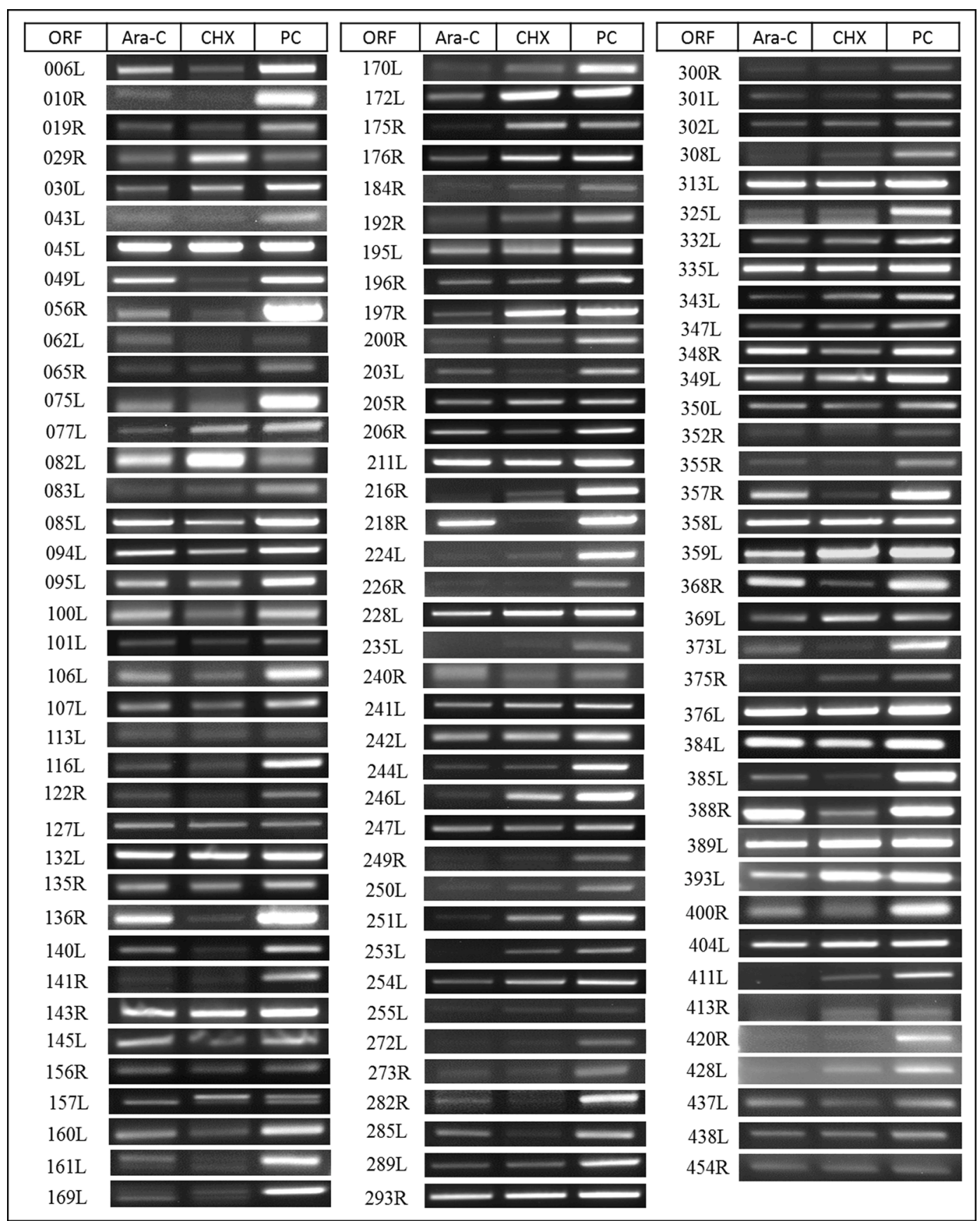

Fig. 1. Immediate-early (IE) gene transcripts of IIV6. Cells were infected with IIV6 in the presence of DNA (Ara-C) or protein synthesis (CHX) inhibitors. ORF-specific RT-PCR was carried out on total RNA isolated at $12 \mathrm{~h}$ post infection. Genes that give a positive RT-PCR signal in the presence of these inhibitors are categorized as IE genes. ORF: open reading frame; Ara-C: DNA synthesis inhibitor (cytosine arabinoside); CHX: protein synthesis inhibitor (cycloheximide). PC: Positive control, infection without addition of inhibitors.

Therefore, upstream sequences of all IIV6 L genes, from which the L1 and L2 motifs were in silico removed, were re-analyzed for the presence of potential promoter sequences using MEME Suite Software, resulting in two additional conserved sequences (motif L3 and motif L4) (Fig. 5). These motifs were individually mutated in PCR fragments that did not contain the L1 and L2 motifs and reporter analysis clearly showed that both motifs L3 and L4 contributed to L promoter activity (Fig. 5).

\section{Discussion}

This study presents extensive information on the transcriptional regulation of invertebrate iridescent virus 6 (IIV6) genes.
Transcriptional studies on iridovirids (members of the family Iridoviridae) have been reported previously for Frog virus 3 (Majji et al., 2009), Singapore grouper iridovirus (Chen et al., 2006; Teng et al., 2008), Red sea bream iridovirus (Lua et al., 2005; Dang et al., 2007; 2008), IIV6 (D'Costa et al., 2001, 2004; Ince et al., 2008; 2013; Nalcacioglu et al., 2003; Dizman et al., 2012) and IIV9 (McMillan and Kalmakoff, 1994). The first transcriptional study on IIV6 genes identified 137 transcripts of which 38 corresponded to IE, 34 in DE and 65 in L temporal classes based on northern blot analysis. However, these authors did not clearly identify the ORFs in their study (D'Costa et al., 2004). Other transcriptional studies on IIV6 genes included temporal classification of a few genes: DNA polymerase (037L), major capsid protein (274L), 

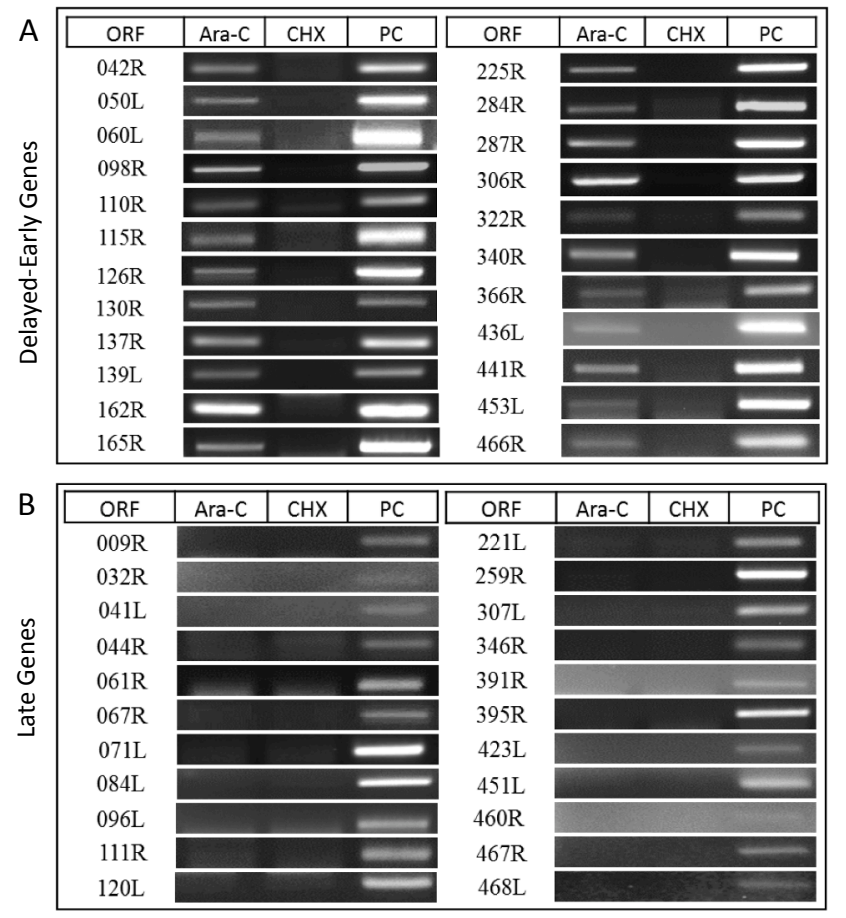

Fig. 2. Delayed-early (DE) and late (L) gene transcripts of IIV6. Cells were infected with IIV6 in the presence of DNA (Ara-C) or protein synthesis (CHX) inhibitors. ORF-specific RT-PCR was carried out on total RNA isolated at $12 \mathrm{~h}$ post infection. Transcripts that were not detected in the presence of the protein synthesis inhibitor (CHX) but were not affected by the DNA synthesis inhibitor are from DE genes (A). Genes that do not show transcripts in the presence of both inhibitors as categorized as L genes (B). ORF: open reading frame; Ara-C: DNA synthesis inhibitor (cytosine arabinoside); CHX: protein synthesis inhibitor (cycloheximide). PC: Positive control, infection without addition of inhibitors.

exonuclease (012L), inhibitor of apoptosis (193R), and putative myristoylated membrane protein (458R) (Nalcacioglu et al., 2003; Ince et al., 2008; Dizman et al., 2012; Aksu, 2017). A further study, performed on IIV6, classified 41 of the 54 structural protein coding genes into temporal classes using a ligation-based amplification of cDNA ends (LACE) technique (Ince et al., 2013). In the present study the remaining IIV6 genes that were not studied until now, have been classified according to their temporal expression class. Reverse transcription polymerase chain reaction (RT-PCR) has been successfully used to identify the gene transcripts using total RNA isolated from virus-infected cells in the presence of protein or viral DNA synthesis inhibitors. Since IIV6 transcripts do not contain a polyA tail (Nalcacioglu et al., 2003), specific primer sets designed for the 170 genes were used to detect the gene specific transcripts. Of these, 158 genes were placed into either of the three temporal classes. Transcripts of the remaining 12 genes (069L, 121R, 146R, 148R, 201R, 212L, 236L, 238R, 315L, 414L, 426R, 463L), could not be detected in the RNA isolated at 12 h.p.i., and also not in RNA samples isolated at other time points between 0 and $24 \mathrm{~h}$ p.i. from cells that were not treated with inhibitors (data not shown). The presence of the corresponding ORFs in the viral genome of our IIV6 isolate was confirmed by PCR (data not shown). The absence of these 12 transcripts may be due to the insect cells that we infected with IIV6 or a relatively low transcription level that prevented detection by RT-PCR. A similar problem was encountered by Ince, et al., (2013) while investigating the temporal classification of the IIV6 structural genes using the LACE technique. In that study, the transcripts of 13 genes $(010 \mathrm{R}, 061 \mathrm{R}$, 084L, 096L, 111R, 130R, 203L, 307L, 325L, 355R, 366R, 395R and 453L) could not be detected, although proteomics was used to identify the corresponding peptides. However, in our study, we have been able to detect and classify the transcripts of these 13 structural protein genes by
Table 2

Temporal classification of CIV gene transcripts based on inhibitor studies.

\begin{tabular}{|c|c|c|c|}
\hline ORF & $\begin{array}{l}\text { RNA } \\
\text { Class }\end{array}$ & Molecular function & Biological process \\
\hline 006L & IE & $\begin{array}{l}\text { Putative KilA-N domain- } \\
\text { containing protein }\end{array}$ & \\
\hline 009R & $\mathrm{L}$ & Unknown & \\
\hline 010R & IE & Transmembrane protein & $\begin{array}{l}\text { integral component of } \\
\text { membrane }\end{array}$ \\
\hline 012L & IE & $\begin{array}{l}\text { Exonuclease activity, nucleic } \\
\text { acid binding }\end{array}$ & \\
\hline 019R & IE & Unknown & \\
\hline 022L* & IE & Helicase activity, ATP binding & \\
\hline 029R & IE & Unknown & \\
\hline 030L & IE & DNA helicase activity & $\begin{array}{l}\text { DNA repair, telomere } \\
\text { maintenance }\end{array}$ \\
\hline 032R & $\mathrm{L}$ & Unknown & \\
\hline 034R* & IE & Unknown & $\begin{array}{l}\text { integral component of } \\
\text { membrane }\end{array}$ \\
\hline 037L* & $\mathrm{DE}$ & $\begin{array}{l}\text { DNA-directed DNA polymerase } \\
\text { activity, DNA binding, } \\
\text { nucleotide binding }\end{array}$ & $\begin{array}{l}\text { DNA replication, viral DNA } \\
\text { genome replication }\end{array}$ \\
\hline $041 \mathrm{~L}$ & $\mathrm{~L}$ & Unknown & \\
\hline 042R & $\mathrm{DE}$ & Unknown & \\
\hline 043L & IE & Unknown & \\
\hline 044R & $\mathrm{L}$ & Unknown & \\
\hline 045L & IE & $\begin{array}{l}\text { DNA topoisomerase type II } \\
\text { (ATP-hydrolyzing) activity, }\end{array}$ & DNA topological change \\
\hline
\end{tabular}

integral component of membrane

integral component of membrane

integral component of membrane

integral component of membrane

integral component of membrane

integral component of membrane

integral component of membrane

integral component of membrane

DNA replication, inteinmediated protein splicing ribonucleoside-diphosphat reductase activity, thioredoxin disulfide as acceptor

094L IE Unknown

095L IE Metal ion binding, Putative RING finger protein

096L L Putative FAS1 domaincontaining protein

098R DE Serine/threonine protein kinase

100L IE NAD + ADP-ribosyltransferase activity

101L IE Unknown

104L* IE Unknown

106L IE Unknown

107L IE DNA binding, DNA-directed 5'$3^{\prime}$ RNA polymerase activity
DNA-templated transcription (continued on next page) 
Table 2 (continued)

\begin{tabular}{|c|c|c|c|}
\hline ORF & $\begin{array}{l}\text { RNA } \\
\text { Class }\end{array}$ & Molecular function & Biological process \\
\hline $110 \mathrm{R}$ & $\mathrm{DE}$ & Unknown & \\
\hline $111 \mathrm{R}$ & $\mathrm{L}$ & Unknown & \\
\hline $113 \mathrm{~L}$ & IE & Unknown & $\begin{array}{l}\text { integral component of } \\
\text { membrane }\end{array}$ \\
\hline $115 R$ & $\mathrm{DE}$ & Unknown & \\
\hline $116 \mathrm{~L}$ & IE & Unknown & \\
\hline $117 \mathrm{~L}^{*}$ & $\mathrm{DE}$ & Unknown & \\
\hline $118 \mathrm{~L}^{*}$ & $\mathrm{IE}$ & Putative myristoylated protein & $\begin{array}{l}\text { integral component of } \\
\text { membrane }\end{array}$ \\
\hline $120 \mathrm{~L}$ & $\mathrm{~L}$ & Unknown & \\
\hline $121 \mathrm{R}$ & ND & $\begin{array}{l}\text { Putative RING finger protein, } \\
\text { metal ion binding }\end{array}$ & \\
\hline $122 \mathrm{R}$ & IE & Unknown & \\
\hline $123 \mathrm{R}^{*}$ & IE & $\begin{array}{l}\text { Protein tyrosine/serine/ } \\
\text { threonine phosphatase } \\
\text { activity, protein tyrosine } \\
\text { phosphatase activity }\end{array}$ & \\
\hline $126 \mathrm{R}$ & $\mathrm{DE}$ & Unknown & \\
\hline $127 \mathrm{~L}$ & IE & Unknown & \\
\hline $130 \mathrm{R}$ & $\mathrm{DE}$ & Unknown & \\
\hline $132 \mathrm{~L}$ & IE & $\begin{array}{l}\text { Metal ion binding, Putative } \\
\text { zinc finger protein }\end{array}$ & \\
\hline $135 \mathrm{R}$ & IE & Unknown & $\begin{array}{l}\text { integral component of } \\
\text { membrane }\end{array}$ \\
\hline $136 \mathrm{R}$ & IE & Metallopeptidase & \\
\hline $137 \mathrm{R}$ & $\mathrm{DE}$ & Unknown & \\
\hline $138 \mathrm{R}^{*}$ & IE & Unknown & $\begin{array}{l}\text { integral component of } \\
\text { membrane }\end{array}$ \\
\hline $139 \mathrm{~L}$ & $\mathrm{DE}$ & Unknown & \\
\hline $140 \mathrm{~L}$ & IE & Unknown & $\begin{array}{l}\text { integral component of } \\
\text { membrane }\end{array}$ \\
\hline $141 \mathrm{R}$ & IE & Unknown & $\begin{array}{l}\text { integral component of } \\
\text { membrane }\end{array}$ \\
\hline $142 R^{*}$ & IE & $\begin{array}{l}\text { Ribonuclease III activity, RNA } \\
\text { binding }\end{array}$ & RNA processing \\
\hline $143 \mathrm{R}$ & IE & $\begin{array}{l}\text { Nucleoside kinase activity, } \\
\text { ATP binding, Putative kinase } \\
\text { protein }\end{array}$ & \\
\hline $145 \mathrm{~L}$ & IE & Unknown & \\
\hline $146 \mathrm{R}$ & ND & $\begin{array}{l}\text { Putative MSV199 domain- } \\
\text { containing protein }\end{array}$ & \\
\hline $148 \mathrm{R}$ & ND & $\begin{array}{l}\text { Putative MSV199 domain- } \\
\text { containing protein }\end{array}$ & \\
\hline $149 L^{*}$ & $\mathrm{DE}$ & Unknown & \\
\hline $155 \mathrm{~L}^{*}$ & IE & Unknown & \\
\hline $156 \mathrm{R}$ & IE & Unknown & \\
\hline $157 \mathrm{~L}$ & IE & $\begin{array}{l}\text { Metal ion binding, Putative } \\
\text { RING finger protein }\end{array}$ & \\
\hline $159 L^{*}$ & $\mathrm{~L}$ & Unknown & \\
\hline $160 \mathrm{~L}$ & IE & Unknown & \\
\hline $161 \mathrm{~L}$ & IE & $\begin{array}{l}\text { Helicase activity, DNA } \\
\text { binding, ATP binding }\end{array}$ & \\
\hline $162 \mathrm{R}$ & $\mathrm{DE}$ & Unknown & \\
\hline $165 \mathrm{R}$ & $\mathrm{DE}$ & $\begin{array}{l}\text { Metalloendopeptidase activity, } \\
\text { zinc ion binding }\end{array}$ & \\
\hline $169 \mathrm{~L}$ & IE & Unknown & $\begin{array}{l}\text { integral component of } \\
\text { membrane }\end{array}$ \\
\hline $170 \mathrm{~L}$ & IE & Unknown & \\
\hline $172 \mathrm{~L}$ & IE & Helicase activity, ATP binding & \\
\hline $175 \mathrm{R}$ & IE & $\begin{array}{l}\text { Putative RING finger protein, } \\
\text { metal ion binding }\end{array}$ & \\
\hline $176 \mathrm{R}$ & IE & $\begin{array}{l}\text { DNA-directed } 5^{\prime}-3^{\prime} \text { RNA } \\
\text { polymerase activity, DNA } \\
\text { binding, metal ion binding }\end{array}$ & DNA-templated transcription \\
\hline $179 R^{*}$ & $\mathrm{DE}$ & Protein kinase activity & \\
\hline $184 \mathrm{R}$ & IE & $\begin{array}{l}\text { Helicase activity, DNA primase } \\
\text { activity, ATP binding, D5 } \\
\text { family NTPase }\end{array}$ & DNA replication \\
\hline $192 \mathrm{R}$ & IE & Unknown & \\
\hline $193 R$ & IE & $\begin{array}{l}\text { Apoptosis inhibitör, metal ion } \\
\text { binding }\end{array}$ & $\begin{array}{l}\text { suppression by virus of host } \\
\text { cysteine-type endopeptidase } \\
\text { activity involved in apoptotic } \\
\text { process }\end{array}$ \\
\hline $195 \mathrm{~L}$ & IE & Unknown & \\
\hline $196 \mathrm{R}$ & IE & Unknown & \\
\hline
\end{tabular}

Table 2 (continued)

\begin{tabular}{|c|c|c|c|}
\hline ORF & $\begin{array}{l}\text { RNA } \\
\text { Class }\end{array}$ & Molecular function & Biological process \\
\hline 197R & IE & $\begin{array}{l}\text { Protein tyrosine/serine/ } \\
\text { threonine phosphatase } \\
\text { activity, protein tyrosine } \\
\text { phosphatase activity }\end{array}$ & \\
\hline $198 \mathrm{R}$ & $\mathrm{L}$ & Unknown & \\
\hline $200 \mathrm{R}$ & IE & $\begin{array}{l}\text { Putative MSV199 domain- } \\
\text { containing protein }\end{array}$ & \\
\hline $201 \mathrm{R}$ & ND & $\begin{array}{l}\text { Putative Bro-N domain- } \\
\text { containing protein }\end{array}$ & \\
\hline 203L & IE & Unknown & $\begin{array}{l}\text { integral component of } \\
\text { membrane }\end{array}$ \\
\hline $205 R$ & IE & DNA ligase (NAD + ) activity & DNA repair, DNA replication \\
\hline 206R & IE & Unknown & \\
\hline $209 R^{*}$ & IE & Unknown & \\
\hline $211 \mathrm{~L}$ & IE & $\begin{array}{l}\text { Putative MSV199 domain- } \\
\text { containing protein, }\end{array}$ & \\
\hline $212 \mathrm{~L}$ & ND & $\begin{array}{l}\text { Putative MSV199 domain- } \\
\text { containing protein }\end{array}$ & \\
\hline 213R & IE & Transmembrane protein & $\begin{array}{l}\text { integral component of } \\
\text { membrane }\end{array}$ \\
\hline $216 R^{\#}$ & IE & Unknown & \\
\hline $218 R$ & IE & Unknown & \\
\hline $219 L^{*}$ & IE & Unknown & \\
\hline $221 \mathrm{~L}$ & $\mathrm{~L}$ & Unknown & \\
\hline $224 \mathrm{~L}$ & IE & $\begin{array}{l}\text { Cysteine-type peptidase } \\
\text { activity }\end{array}$ & $\begin{array}{l}\text { integral component of } \\
\text { membrane }\end{array}$ \\
\hline $225 \mathrm{R}$ & $\mathrm{DE}$ & Thymidylate synthase activity & $\begin{array}{l}\mathrm{dTMP} / \mathrm{dTTP} \text { biosynthetic } \\
\text { process }\end{array}$ \\
\hline $226 \mathrm{R}$ & IE & Unknown & \\
\hline $227 L^{*}$ & IE & Unknown & $\begin{array}{l}\text { integral component of } \\
\text { membrane }\end{array}$ \\
\hline $228 \mathrm{~L}$ & IE & Unknown & \\
\hline $229 L^{*}$ & $\mathrm{DE}$ & Unknown & \\
\hline $232 \mathrm{R}^{*}$ & IE & $\begin{array}{l}\text { Thiol-dependent ubiquitinyl } \\
\text { hydrolase activity }\end{array}$ & $\begin{array}{l}\text { DNA-templated } \\
\text { transcription, termination }\end{array}$ \\
\hline $234 \mathrm{R}^{*}$ & $\mathrm{~L}$ & Unknown & $\begin{array}{l}\text { integral component of } \\
\text { membrane }\end{array}$ \\
\hline $235 \mathrm{~L}^{\#}$ & IE & Methyltransferase activity & \\
\hline $236 \mathrm{~L}$ & ND & Unknown & \\
\hline $238 \mathrm{R}$ & ND & $\begin{array}{l}\text { Putative MSV199 domain- } \\
\text { containing protein }\end{array}$ & \\
\hline $240 \mathrm{R}$ & IE & Unknown & \\
\hline $241 \mathrm{~L}$ & IE & $\begin{array}{l}\text { Cysteine-rich uncharacterized } \\
\text { protein }\end{array}$ & \\
\hline $242 \mathrm{~L}$ & IE & $\begin{array}{l}\text { Putative GIY-YIG domain- } \\
\text { containing protein, nuclease } \\
\text { activity }\end{array}$ & DNA manipulation \\
\hline $244 \mathrm{~L}$ & IE & $\begin{array}{l}\text { Hydrolase activity, metal ion } \\
\text { binding }\end{array}$ & \\
\hline $246 \mathrm{~L}$ & IE & Unknown & \\
\hline 247L & IE & Unknown & \\
\hline $249 R$ & IE & Unknown & \\
\hline $250 \mathrm{~L}$ & IE & Unknown & \\
\hline $251 \mathrm{~L}$ & IE & $\begin{array}{l}\text { Thymidylate kinase activity, } \\
\text { ATP binding }\end{array}$ & $\begin{array}{l}\text { dTDP/dTTP biosynthetic } \\
\text { process }\end{array}$ \\
\hline $253 \mathrm{~L}^{\#}$ & IE & Unknown & \\
\hline $254 \mathrm{~L}$ & IE & Unknown & \\
\hline $255 \mathrm{~L}$ & IE & Unknown & \\
\hline $259 R$ & $\mathrm{~L}$ & Unknown & $\begin{array}{l}\text { integral component of } \\
\text { membrane }\end{array}$ \\
\hline $261 R^{*}$ & IE & Unknown & \\
\hline $268 \mathrm{~L}^{*}$ & IE & Unknown & \\
\hline $272 \mathrm{~L}$ & IE & Unknown & \\
\hline 273R & IE & Unknown & \\
\hline $274 L^{*}$ & $\mathrm{~L}$ & Structural molecule activity & $\begin{array}{l}\text { Major capsid protein, viral } \\
\text { capsid }\end{array}$ \\
\hline $282 \mathrm{R}$ & IE & $\begin{array}{l}\text { Putative transcription factor, } \\
\text { Putative replication factor } \\
\text { and/or DNA binding/ } \\
\text { packaging protein }\end{array}$ & $\begin{array}{l}\text { regulation of viral } \\
\text { transcription }\end{array}$ \\
\hline $284 \mathrm{R}$ & $\mathrm{DE}$ & Unknown & \\
\hline $285 \mathrm{~L}$ & $\mathrm{IE}$ & Unknown & \\
\hline $287 R$ & $\mathrm{DE}$ & Unknown & \\
\hline $289 \mathrm{~L}$ & IE & $\begin{array}{l}\text { Putative Bro-N domain- } \\
\text { containing protein }\end{array}$ & \\
\hline
\end{tabular}


Table 2 (continued)

\begin{tabular}{|c|c|c|c|}
\hline ORF & $\begin{array}{l}\text { RNA } \\
\text { Class }\end{array}$ & Molecular function & Biological process \\
\hline 293R & IE & Unknown & \\
\hline $295 L^{*}$ & IE & $\begin{array}{l}\text { Vaccinia virus early } \\
\text { transcription factor }\end{array}$ & $\begin{array}{l}\text { integral component of } \\
\text { membrane }\end{array}$ \\
\hline $300 \mathrm{R}$ & IE & Transmembrane protein & $\begin{array}{l}\text { integral component of } \\
\text { membrane }\end{array}$ \\
\hline $301 \mathrm{~L}$ & IE & Unknown & \\
\hline $302 \mathrm{~L}$ & IE & $\begin{array}{l}\text { Putative zinc finger protein, } \\
\text { metal ion binding, nucleic acid } \\
\text { binding }\end{array}$ & \\
\hline $306 \mathrm{R}$ & $\mathrm{DE}$ & $\begin{array}{l}\text { Putative SWIB domain- } \\
\text { containing protein }\end{array}$ & \\
\hline 307L & $\mathrm{L}$ & Uvr/REP helicase & $\begin{array}{l}\text { integral component of } \\
\text { membrane }\end{array}$ \\
\hline 308L & IE & Unknown & \\
\hline 309L* & IE & Unknown & \\
\hline $312 R^{*}$ & IE & Unknown & \\
\hline 313L & IE & $\begin{array}{l}\text { Putative KilA-N domain- } \\
\text { containing protein }\end{array}$ & \\
\hline $315 \mathrm{~L}$ & ND & $\begin{array}{l}\text { Putative KilA-N domain- } \\
\text { containing protein }\end{array}$ & \\
\hline $317 L^{*}$ & $\mathrm{~L}$ & Unknown & \\
\hline $322 \mathrm{R}$ & $\mathrm{DE}$ & Unknown & \\
\hline $325 \mathrm{~L}$ & IE & Unknown & $\begin{array}{l}\text { integral component of } \\
\text { membrane }\end{array}$ \\
\hline $329 R^{*}$ & $\mathrm{DE}$ & Unknown & \\
\hline $332 \mathrm{~L}$ & IE & $\begin{array}{l}\text { Uncharacterized RING finger } \\
\text { protein, metal ion binding }\end{array}$ & \\
\hline $335 \mathrm{~L}$ & IE & Unknown & \\
\hline $337 L^{*}$ & $\mathrm{DE}$ & $\begin{array}{l}\text { Putative membrane protein, } \\
\text { Myristylated membrane } \\
\text { protein }\end{array}$ & $\begin{array}{l}\text { virion membrane, integral } \\
\text { component of membrane }\end{array}$ \\
\hline $340 \mathrm{R}$ & $\mathrm{DE}$ & $\begin{array}{l}\text { DRBM domain-containing } \\
\text { protein, RNA binding }\end{array}$ & \\
\hline $342 R^{*}$ & $\mathrm{~L}$ & Unknown & \\
\hline 343L & IE & $\begin{array}{l}\text { Probable DNA-directed RNA } \\
\text { polymerase subunit, DNA- } \\
\text { directed } 5^{\prime}-3^{\prime} \text { RNA polymerase } \\
\text { activity, DNA binding }\end{array}$ & DNA-templated transcription \\
\hline $346 \mathrm{R}$ & $\mathrm{L}$ & Unknown & \\
\hline $347 \mathrm{~L}$ & IE & $\begin{array}{l}\text { Flavin-linked sulfhydryl } \\
\text { oxidase activity }\end{array}$ & \\
\hline $348 \mathrm{R}$ & IE & Unknown & \\
\hline $349 \mathrm{~L}$ & IE & $\begin{array}{l}\text { Putative transcription } \\
\text { elongation factor S-II-like } \\
\text { protein, nucleic acid binding, } \\
\text { zinc ion binding }\end{array}$ & DNA-templated transcription \\
\hline $350 \mathrm{~L}$ & IE & Unknown & \\
\hline $352 \mathrm{~L}$ & IE & Unknown & \\
\hline $355 \mathrm{R}$ & IE & $\begin{array}{l}\text { Putative CTD phosphatase-like } \\
\text { protein, phosphoprotein } \\
\text { phosphatase activity }\end{array}$ & \\
\hline $357 R$ & IE & Unknown & \\
\hline $358 \mathrm{~L}$ & IE & Unknown & \\
\hline 359L & IE & Unknown & \\
\hline $361 L^{*}$ & IE & $\begin{array}{l}\text { Probable cysteine proteinase, } \\
\text { cysteine-type peptidase } \\
\text { activity }\end{array}$ & $\begin{array}{l}\text { integral component of } \\
\text { membrane }\end{array}$ \\
\hline $366 \mathrm{R}$ & $\mathrm{DE}$ & Unknown & \\
\hline $368 \mathrm{R}$ & IE & Unknown & \\
\hline $369 \mathrm{~L}$ & IE & $\begin{array}{l}\text { Probable RAD2-like } \\
\text { endonuclease, endonuclease } \\
\text { activity, metal ion binding }\end{array}$ & DNA repair, host cell nucleus \\
\hline 373L & IE & Unknown & \\
\hline $374 R^{*}$ & $\mathrm{DE}$ & Unknown & \\
\hline $375 \mathrm{R}$ & IE & Unknown & \\
\hline $376 \mathrm{~L}$ & IE & $\begin{array}{l}\text { Metal ion binding, } \\
\text { ribonucleoside-diphosphate } \\
\text { reductase activity, thioredoxin } \\
\text { disulfide as acceptor }\end{array}$ & $\begin{array}{l}\text { deoxyribonucleotide } \\
\text { biosynthetic process, DNA } \\
\text { replication }\end{array}$ \\
\hline $378 R^{*}$ & $\mathrm{DE}$ & Unknown & \\
\hline $380 \mathrm{R}^{*}$ & IE & $\begin{array}{l}\text { Protein serine/threonine } \\
\text { kinase activity, ATP binding }\end{array}$ & \\
\hline $384 \mathrm{~L}$ & IE & Unknown & \\
\hline $385 \mathrm{~L}$ & IE & Unknown & \\
\hline 388R & IE & & \\
\hline
\end{tabular}

Table 2 (continued)

\begin{tabular}{|c|c|c|c|}
\hline ORF & $\begin{array}{l}\text { RNA } \\
\text { Class }\end{array}$ & Molecular function & Biological process \\
\hline & & $\begin{array}{l}\text { Putative MSV199 domain- } \\
\text { containing protein }\end{array}$ & \\
\hline $389 \mathrm{~L}$ & IE & $\begin{array}{l}\text { Protein serine/threonine } \\
\text { kinase activity, ATP binding }\end{array}$ & \\
\hline $391 \mathrm{R}$ & $\mathrm{L}$ & Chaperone binding & \\
\hline 393L & IE & $\begin{array}{l}\text { Immediate-early protein ICP- } \\
46 \text { homolog }\end{array}$ & \\
\hline $395 \mathrm{R}$ & $\mathrm{L}$ & Unknown & \\
\hline $396 L^{*}$ & $\mathrm{DE}$ & Unknown & \\
\hline $400 \mathrm{R}$ & IE & Unknown & \\
\hline $401 R^{*}$ & $\mathrm{~L}$ & $\begin{array}{l}\text { High mobility group protein } \\
\text { homolog, HMG box DNA } \\
\text { binding }\end{array}$ & host cell nucleus \\
\hline $404 \mathrm{~L}$ & IE & Unknown & \\
\hline $411 L^{\#}$ & IE & Unknown & \\
\hline $413 R^{\#}$ & IE & $\begin{array}{l}\text { Putative RING finger protein, } \\
\text { metal ion binding }\end{array}$ & \\
\hline $414 \mathrm{~L}$ & ND & $\begin{array}{l}\text { Putative hydrolase, hydrolase } \\
\text { activity, metal ion binding }\end{array}$ & \\
\hline $415 R^{*}$ & IE & Unknown & \\
\hline $420 \mathrm{R}$ & IE & $\begin{array}{l}\text { Putative MSV199 domain- } \\
\text { containing protein }\end{array}$ & \\
\hline $422 L^{*}$ & $\mathrm{DE}$ & Unknown & \\
\hline 423L & $\mathrm{L}$ & Unknown & \\
\hline $426 \mathrm{R}$ & ND & Unknown & \\
\hline $428 \mathrm{~L}$ & IE & $\begin{array}{l}\text { Probable DNA-directed RNA } \\
\text { polymerase II subunit RPB2 } \\
\text { homolog, DNA-directed } 5^{\prime}-3^{\prime} \\
\text { RNA polymerase activity, DNA } \\
\text { binding, metal ion binding, } \\
\text { ribonucleoside binding }\end{array}$ & DNA-templated transcription \\
\hline $436 \mathrm{R}$ & $\mathrm{DE}$ & $\begin{array}{l}\text { Proliferating cell nuclear } \\
\text { antigen (PCNA) }\end{array}$ & \\
\hline 437L & IE & Unknown & \\
\hline $438 \mathrm{~L}$ & IE & dUTP diphosphatase activity & $\begin{array}{l}\text { dUMP/dUTP biosynthetic } \\
\text { process }\end{array}$ \\
\hline $439 L^{*}$ & IE & $\begin{array}{l}\text { Probable kinase, protein kinase } \\
\text { activity, ATP binding }\end{array}$ & \\
\hline $441 \mathrm{R}$ & $\mathrm{DE}$ & Unknown & \\
\hline $443 R^{*}$ & IE & Unknown & \\
\hline $451 \mathrm{~L}$ & $\mathrm{~L}$ & Unknown & \\
\hline $453 \mathrm{~L}$ & $\mathrm{DE}$ & $\begin{array}{l}\text { Putative thioredoxin-like } \\
\text { protein }\end{array}$ & oxidation-reduction process \\
\hline $454 \mathrm{R}$ & IE & $\begin{array}{l}\text { Putative DNA-directed RNA } \\
\text { polymerase subunit, DNA- } \\
\text { directed } 5^{\prime}-3^{\prime} \text { RNA polymerase } \\
\text { activity, DNA binding }\end{array}$ & DNA-templated transcription \\
\hline $457 \mathrm{~L}$ & $\mathrm{DE}$ & Unknown & \\
\hline $458 \mathrm{R}$ & $\mathrm{L}$ & $\begin{array}{l}\text { Putative myristoylated } \\
\text { membrane protein }\end{array}$ & $\begin{array}{l}\text { integral component of } \\
\text { membrane }\end{array}$ \\
\hline $460 \mathrm{R}$ & $\mathrm{L}$ & Unknown & \\
\hline $463 \mathrm{~L}$ & ND & $\begin{array}{l}\text { Probable lipid hydrolase, } \\
\text { hydrolase activity }\end{array}$ & lipid catabolic process \\
\hline $466 \mathrm{R}$ & $\mathrm{DE}$ & Unknown & $\begin{array}{l}\text { integral component of } \\
\text { membrane }\end{array}$ \\
\hline $467 \mathrm{R}$ & $\mathrm{L}$ & Unknown & \\
\hline $468 \mathrm{~L}$ & $\mathrm{~L}$ & $\begin{array}{l}\text { Putative MSV199 domain- } \\
\text { containing protein }\end{array}$ & \\
\hline
\end{tabular}

Stars (*) indicate that previously determined ORFs. Hash $\left({ }^{\#}\right)$ symbols show the transcripts which are detected in the presence of CHX, but not determined in the presence of Ara-C, so those are classified as immediate early genes. IE, immediate early; DE, delayed early; L, late; ND, not determined. Molecular functions and biological process were obtained from UniProt database according to gene ontology. Grey shaded ORFs are core genes among all iridovirids.

RT-PCR. Bioinformatics analysis showed that most of the 12 remaining unclassified genes in the IIV6 genome contain domains associated with DNA binding; Bro-N (069L, 201R), RING finger (121R), MSV199 (146R, 148R, 212L, 238R) and KilA-N (315L). Also, two of these unclassified genes, 414L and 463L, have hydrolase activity.

Five ORFs (216R, 235L, 253L, 411L, 413R) were detected in the presence of the protein synthesis inhibitor (consistent with their 
IE



A
DE

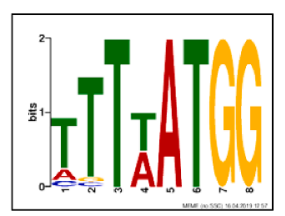

B
L1

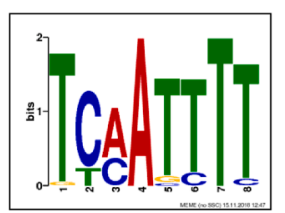

C
L2

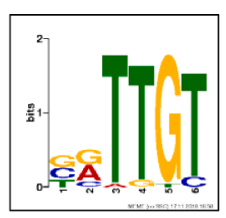

D

Fig. 3. Predicted motifs within the upstream sequences of IIV6 ORFs. Genes were categorized in temporal classes based on the experimental and literature data. Conserved motifs were searched for per temporal class by analysing the 200-nt sequences upstream of the annotated IIV6 translation start sites using MEME software. Parameters were set to zero or one occurrence per sequence and the program searched the coding strand only. Single motifs were obtained for (A) immediate early (IE) and (B) delayed early (DE) genes, while late (L) genes (C and D) contained two motifs (L1) and L2).

A

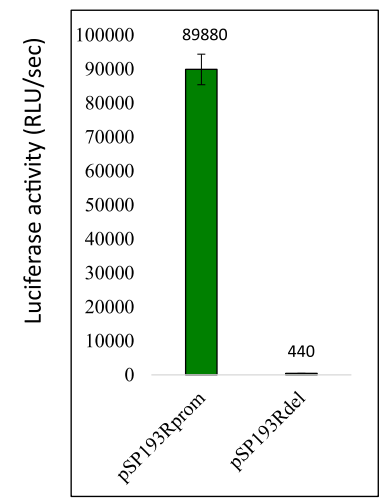

B

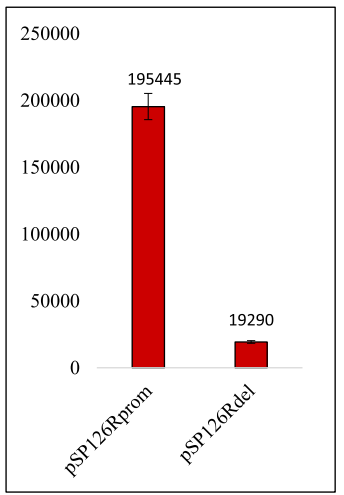

C



Fig. 4. Luciferase activities of promoter reporter plasmids of immediate-early (193R) (A), delayed-early (126R) (B) and late (259R, 084L, 061R) (C) ORFs with and without the motifs shown in Fig. 3. The prom and del extensions in the plasmid names refer to plasmids with and without the motifs, respectively. RLU/sec; relative light units emitted per second.

classification as IE genes), but not in the presence of the DNA synthesis inhibitor (consistent with their classification as L genes). This result was therefore not conforming the defined temporal groups. However, since these transcripts were detected in the presence of protein synthesis inhibitor like IE genes, they were also accepted as the products of IE genes. These genes may be transactivated early in infection by already existing proteins in the virion structure (IE), but at the same time be expressed in the late stage so that their gene products could be incorporated in the virion and may themselves assist in the transactivation process. A similar result was obtained for 219L and 295L by Ince et al., (2013).

So, more than half of the IIV6 genome can be immediately transcribed, most likely due to the action of transactivators incorporated in the viral particles. Compared to the other iridovirids (Majji et al., 2009; Chen et al., 2006; Teng et al., 2008; Dang et al., 2007), IIV6 has the highest number of ORFs in the IE class.

Among the 98 putative ORFs of Frog virus 3 (FV3), 31 have corresponding homologous in IIV6 (Tan et al., 2004). However, the temporal classes of these 31 IIV6 ORFs are mostly inconsistent with their counterparts in the FV3 transcriptome (Majji et al., 2009). For most of these homologues these inconsistencies differed by only one temporal class. Whether IIV6 has a closer resemblance in respect to transcriptional classes of its genes to invertebrate iridoviruses needs to be determined. Furthermore, the fact that genes are classified as IE genes, does not imply that a number of these genes may not continue to be expressed in the DE phase, or are expressed subsequently as late class transcripts, as we observed for a small number of IIV genes (D'Costa et al., 2001).

The obtained information on the temporal classes of almost all predicted IIV6 genes provided the basis for identifying whether ORFs in the same temporal class contained common upstream regulatory regions. The MEME Suite program identified the AA(A/T)(T/A)TG(A/G)A motif in the upstream sequence of all identified IE genes of IIV6. Previously, Dizman et al. (2012) mapped the limits of the putative promoter region of the IIV6 IE gene 012L using reporter gene assays. The in silico identified upstream motif is indeed present within the experimentally identified promoter region of 012L. The IIV6 DNA polymerase gene (037L) was reported previously as a DE class gene and it was shown experimentally that an AAAAT motif was essential for promoter activity (Nalcacioglu et al., 2007). The most prevalent motif, (T/A/C)(T/G/C)T (T/A)ATGG, identified for DE gene promoters is not present in the upstream sequence of 037L.

Two conserved motifs without promoter activity were detected in the upstream sequences of IIV6 L genes. Motif L2, ending with the sequence $(T / A)(T / G)(G / T)(T / C)$ served as cis-acting repressor element for the ORF downstream, at least for the three ORFs (259R, 061L, 084L) tested in this study. The promoter region of the $m c p$ has been analyzed previously (Nalcacioglu et al., 2003) and contains several repeats of motif L2. A $m c p$ promoter construct starting at -53 relative to the ATG start codon, contained such a motif and had a high promoter activity, but the construct -23 that lacked this motif had reduced promoter activity in the luciferase reporter assay (Nalcacioglu et al., 2003). According to that result we may conclude that this motif does not function as a repressor for all IIV6 L genes, and it may be the context in which motif L2 is present is also important. Cis-acting repressor elements have been reported for a few viruses including Human cytomegalovirus (HCMV) (Biegalke, 1995; Lashmit et al., 1998), Equine herpesvirus 1 (EHV-1) (Ahn et al., 2010), Human Immunodeficiency Virus Type 1 (HIV-1) (Huffman and Arrigo, 1997) but to our knowledge this is the first identification of such an element in an insect virus.

Investigation of promoter motifs, using a computer program combined with biological assays, has been recently performed for Marseilleviruses (Marseillevirus genus, Marseilleviridae family) (Oliveira et al., 2017a). They detected an eight-nucleotide A/T-rich promoter sequence (AAATATTT) associated with $55 \%$ of the Marseillevirus genes. The IE motif, AA(A/T)(T/A)TG(A/G)A, we detected in the IIV6 genome was 




Fig. 5. Detection and analysis of additional upstream motifs for late genes. The position of the four identified motifs in the upstream region exemplified for ORF 061R. The mutated motifs are indicated with yellow boxes. The mutations made in these motifs are illustrated in red text. Luciferase activities of deletion and site directed-mutated promoter plasmids were compared to the wild type sequence for 061R. RLU/sec; relative light units emitted per second.

associated with the majority (68\%) of viral genes. Furthermore, a specific $8 \mathrm{nt}$ conserved motif, AAAATTGA, has been found in nearly $50 \%$ of IE (or DE) gene promoters in the Mimivirus genome (Mimivirus genus, Mimiviridae family) (Suhre et al., 2005). The similarity of this motif with the IIV6 IE motif is remarkable. In a review by Oliveira et al. (2017b), the currently available information about promoter regions in nucleocytoplasmic large DNA viruses (NCLDV), including iridovirids, was discussed. The fact that some promoter sequences found in one family are very similar to those found in their relatives suggest a common origin for NCLDVs genes and a promoter motif (TATATAAAATTGA) with the name "MEGA-box" was proposed for their common ancestor. The authors of the review suggested that the MEGA-box has been gradually evolved by nucleotide gain and loss into the functional promoters in the present-day NCLDVs. The resemblance of the IIV6 IE motif found in our study to the MEGA-box sequence reinforces this hypothesis.

Here, we have presented a study including both experimental and in silico analysis on transcriptional regulators of IIV6. Two hundred and three (158 in this study, 45 previously) of the 215 ORFs in the IIV6 genome have now been classified and include 138 IE genes, 35 DE genes and $30 \mathrm{~L}$ genes. Motifs detected in the upstream regions of the genes further delineate the temporal classes. The fact that all IE class genes contain the motif detected by the computer program increases the probability that this motif will essential for promoter activity for all IIV6 IE genes. This information increases our understanding the molecular mechanisms of IIV6 infection.

\section{Declaration of Competing Interest}

The authors declare that they have no known competing financial interests or personal relationships that could have appeared to influence the work reported in this paper.

\section{Acknowledgement}

This study was supported by a 2214/a scholarship (Project no: 214Z172) to Aydin Yesilyurt from the Scientific and Technological Research Council of Turkey (TUBITAK) allowing him to do part of his studies at Wageningen University, the Netherlands and a research grant from the Karadeniz Technical University (Project no. 5839).

\section{Appendix A. Supplementary data}

Supplementary data to this article can be found online at https://doi. org/10.1016/j.jip.2020.107496.

\section{References}

Ahn, B.C., Zhang, Y., O'Callaghan, D.J., 2010. The equine herpesvirus-1 (EHV-1) IR3 transcript downregulates expression of the IE gene and the absence of IR3 gene expression alters EHV-1 biological properties and virulence. Virology 402, 327-337.

Aksu, C.., 2017. Molecular characterization of Chilo iridescent virus 458R open reading frame. Master Thesis. Karadeniz Technical University.

Bailey, T.L., Boden, M., Buske, F.A., Frith, M., Grant, C.E., Clementi, L., Ren, J., Li, W.W., Noble, W.S., 2009. MEME Suite: tools for motif discovery and searching. Nucleic Acids Res. 37, W202-W208.

Biegalke, B.J., 1995. Regulation of human cytomegalovirus US3 gene transcription by a cis-repressive sequence. J. Virol. 69, 5362-5367.

Cerutti, M., Cerutti, P., Devauchelle, G., 1989. Infectivity of vesicles prepared from chilo iridescent virus inner membrane: evidence for recombination between associated DNA fragments. Virus Res. 12, 299-313.

Chen, L.M., Wang, F., Song, W., Hew, C.L., 2006. Temporal and differential gene expression of Singapore grouper iridovirus. J. Gen. Virol. 87, 2907-2915.

Chinchar, V.G., Hick, P., Ince, I.A., Jancovich, J.K., Marschang, R., Qin, Q. Subramaniam, K., Waltzek, T.B., Whittington, R., Williams, T., Zhang, Q.Y., Ictv Report, C., 2017. ICTV Virus Taxonomy Profile: Iridoviridae. J. Gen. Virol. 98, $890-891$.

Cook, J.K.A., Darbyshire, J.H., Peters, R.W., 1976. Growth kinetic studies of avian infectious bronchitis virus in tracheal organ cultures. Res. Vet. Sci. 20, 348-349.

Dang, T.L., Yasuike, M., Hirono, I., Kondo, H., Aoki, T., 2007. Transcriptional profile of red seabream iridovirus in a fish model as revealed by viral DNA microarrays. Virus Genes 35, 449-461.

Dang, T.L., Kondo, H., Hirono, I., Aoki, T., 2008. Inhibition of red seabream iridovirus (RSIV) replication by small interfering RNA (siRNA) in a cell culture system. Antiviral Res. 77, 142-149.

D'Costa, S.M., Yao, H., Bilimoria, S.L., 2001. Transcription and temporal cascade in Chilo iridescent virus infected cells. Arch. Virol. 146, 2165-2178.

D'Costa, S.M., Yao, H.J., Bilimoria, S.L., 2004. Transcriptional mapping in Chilo iridescent virus infections. Arch. Virol. 149, 723-742.

Dizman, Y.A., Demirbag, Z., Ince, I.A., Nalcacioglu, R., 2012. Transcriptomic analysis of Chilo iridescent virus immediate early promoter. Virus Res. 167, 353-357.

Eaton, H.E., Metcalf, J., Penny, E., Tcherepanov, V., Upton, C., Brunetti, C.R., 2007. Comparative genomic analysis of the family Iridoviridae: re-annotating and defining the core set of iridovirus genes. Virol. J. 4, 11.

Goorha, R., 1982. Frog virus 3 DNA replication occurs in two stages. J. Virol. 43, 519-528.

Granoff, A., 1984. Frog virus 3: A DNA virus with an unusual life-style. Prog. Med. Virol. 30, 187-198.

Huffman, K.M., Arrigo, S.J., 1997. Identification of cis-acting repressor activity within human immunodeficiency virus type 1 protease sequences. Virology 234, 253-260.

Ince, I.A., Boeren, S.A., van Oers, M.M., Vervoort, J.J., Vlak, J.M., 2010. Proteomic analysis of Chilo iridescent virus. Virology 405, 253-258.

Ince, I.A., Ozcan, K., Vlak, J.M., van Oers, M.M., 2013. Temporal classification and mapping of non-polyadenylated transcripts of an invertebrate iridovirus. J. Gen. Virol. 94, 187-192.

Ince, I.A., Westenberg, M., Vlak, J.M., Demirbag, Z., Nalcacioglu, R., van Oers, M.M., 2008. Open reading frame 193R of Chilo iridescent virus encodes a functional inhibitor of apoptosis (IAP). Virology 376, 124-131.

Jakob, N.J., Darai, G., 2002. Molecular anatomy of Chilo iridescent virus genome and the evolution of viral genes. Virus Genes 25, 299-316.

Lashmit, P.E., Stinski, M.F., Murphy, E.A., Bullock, G.C., 1998. A cis-repression sequence adjacent to the transcription start site of the human cytomegalovirus US3 gene is required to down regulate gene expression at early and late times after infection. J Virol. 72, 9575-9584.

Lua, D.T., Yasuike, M., Hirono, I., Aoki, T., 2005. Transcription Program of Red Sea Bream Iridovirus as Revealed by DNA Microarrays. J. Virol. 79, 15151-15164. 
Majji, S., Thodima, V., Sample, R., Whitley, D., Deng, Y., Mao, J., Chinchar, V.G., 2009. Transcriptome analysis of Frog virus 3, the type species of the genus Ranavirus, family Iridoviridae. Virology 391, 293-303.

McMillan, N., Kalmakoff, J., 1994. RNA transcript mapping of the Wiseana iridescent virus genome. Virus Res. 32, 343-352.

Nalcacioglu, R., Ince, I.A., Vlak, J.M., Demirbag, Z., van Oers, M.M., 2007. The Chilo iridescent virus DNA polymerase promoter contains an essential AAAAT motif. J. Gen. Virol. 88, 2488-2494.

Nalcacioglu, R., Marks, H., Vlak, J.M., Demirbag, Z., van Oers, M.M., 2003. Promoter analysis of the Chilo iridescent virus DNA polymerase and major capsid protein genes. Virology 317, 321-329.

Oliveira, G.P., Andrade, A.C., Rodrigues, R.A., Arantes, T.S., Boratto, P.V., Silva, L.K., Dornas, F.P., Trindade, G.S., Drumond, B.P., La Scola, B., Kroon, E.G., Abrahão, J.S. 2017a. Promoter motifs in NCLDVs: An evolutionary perspective. Viruses 9, 16.

Oliveira, G.P., Lima, M.T., Arantes, T.S., Assis, F.L., Rodrigues, R.A.L., da Fonseca, F.G., Bonjardim, C.A., Kroon, E.G., Colson, P., La Scola, B., Abrahao, J.S., 2017b. The investigation of promoter sequences of marseilleviruses highlights a remarkable abundance of the AAATATTT motif in intergenic regions. J. Virol. 91, e01088-e1117.

Suhre, K., Audic, S., Claverie, J.M., 2005. Mimivirus gene promoters exhibit an unprecedented conservation among all eukaryotes. Proc. Natl. Acad. Sci. USA 102, 14689-14693.

Tan, W.G., Barkman, T.J., Gregory Chinchar, V., Essani, K., 2004. Comparative genomic analyses of frog virus 3 , type species of the genus Ranavirus (family Iridoviridae). Virology 323, 70-84.

Teng, Y., Hou, Z., Gong, J., Liu, H., Xie, X., Zhang, L., Chen, X., Qin, Q.W., 2008. Wholegenome transcriptional profiles of a novel marine fish iridovirus, Singapore grouper iridovirus (SGIV) in virus-infected grouper spleen cell cultures and in orange-spotted grouper, Epinephulus coioides. Virology 377, 39-48.

Williams, T., Bergoin, M., van Oers, M.M., 2017. Diversity of large DNA viruses of invertebrates. J. Invertebr. Pathol. 147, 4-22.

Williams, T., Ward, V., 2010. Iridoviruses. In: Assgari, S., Johnson, K. (Eds.), Insect Virology. Caister Academic Press, UK, pp. 123-152. 